\title{
Glucocorticoid-induced osteoporosis: an update
}

\author{
Juliet Compston $\mathbb{B D}^{1}$
}

Received: 27 December 2017 / Accepted: 22 March 2018 / Published online: 24 April 2018

(c) The Author(s) 2018

\begin{abstract}
Glucocorticoid-induced osteoporosis is the most common secondary cause of osteoporosis and the resulting fractures cause significant morbidity. Following initiation of oral glucocorticoids, rapid bone loss occurs, and fracture risk increases within a few months in a dose-dependent manner. These adverse effects are due to inhibition of bone formation accompanied by an early but transient increase in bone resorption. Multiple mechanisms underlie these changes in bone remodeling; direct effects include upregulation of PPAR $\gamma R 2$, increased expression of sclerostin and increased RANKL/OPG ratio, whilst hypogonadism, altered renal and intestinal calcium handling, and reduced production of insulin-like growth factor 1 also contribute. Fracture risk assessment should be performed as soon as possible after glucocorticoids are initiated and bone protective therapy started promptly in individuals at high-risk, with calcium and vitamin D supplements where appropriate. Oral bisphosphonates are currently regarded as first line options on the grounds of their low cost. However, teriparatide has been shown to be superior in its effects on BMD and vertebral fracture risk in glucocorticoid-treated individuals with osteoporosis and should be considered as an alternative first line option in high-risk patients.
\end{abstract}

Key words Glucocorticoids $\cdot$ Bone density $\cdot$ Fracture $\cdot$ Bisphosphonates $\cdot$ Teriparatide

\section{Introduction}

Glucocorticoids are used in the treatment of a wide range of diseases and it is estimated that $1-2 \%$ of the population is receiving long-term glucocorticoid therapy [1-4]. The adverse skeletal effects of glucocorticoid excess were first described over 80 years ago, and today glucocorticoidinduced osteoporosis is the most common secondary cause of osteoporosis. Research into the epidemiology, pathophysiology and clinical management of glucocorticoidinduced osteoporosis has produced substantial advances, yet the condition remains under-recognized and under-treated. This review focuses on recent developments in the field and their implications for clinical practice.

Juliet Compston

jec1001@cam.ac.uk

1 Department of Medicine, Cambridge Biomedical Campus, Cambridge CB2 0SL, UK

\section{Epidemiology}

Continuous oral glucocorticoid therapy is associated with rapid bone loss and an increase in fracture risk that is seen within 3-6 months of initiation and is dose-related. This time course can be explained, at least in part, by the higher doses of glucocorticoids and greater disease activity in the early stages of treatment. Fracture risk remains elevated for the duration of glucocorticoid therapy, but declines after its withdrawal, although whether it reverts to baseline values is unclear [5-8]. Vertebral fractures are particularly characteristic of glucocorticoid-induced osteoporosis, although the risk of non-vertebral fractures, including hip fractures, is also increased.

Recent studies have confirmed the predilection for vertebral fracture, the dose-related increase in fracture risk, and decline in fracture risk with longer duration or discontinuation of glucocorticoid therapy. Amiche et al conducted a Bayesian meta-analysis of fracture risk associated with oral glucocorticoid use, drawing on data from the control groups of clinical trials [9]. In individuals who had initiated glucocorticoid therapy in the last 6 months, the annual incidence of vertebral fracture was 5.1\% [95\% credible intervals (CrI) 2.8-8.2] and of non-vertebral fracture, $2.5 \%$ [95\% CrI 1.2-4.2]. For those with duration 
of glucocorticoid use $\geq 6$ months, the corresponding figures were $3.2 \%$ [95\% CrI 1.8-5.0] and 3.0\% [95\% CrI 0.8-5.0]. Using a large administrative database, Balasubramanian et al investigated the effects of initiating systemic (oral or injected) glucocorticoid therapy on fracture risk in patients with new-onset rheumatoid arthritis (mean age 49 years) [10]. Fracture incidence rates were 5 to $9 / 1000$ person years at doses of $<15 \mathrm{mg} /$ day, $16(11,22.6)$ at doses $\geq 15 \mathrm{mg} /$ day and $13.4(10.7,16.7)$ at cumulative doses $\geq 5400 \mathrm{mg}$. At $60-182$ days after discontinuation of glucocorticoid therapy, fracture risk was $29 \%$ lower than in those with ongoing use and by 12 months was similar to nonglucocorticoid users.

The effects of inhaled or intravenous glucocorticoids on fracture risk are less well documented. There is some evidence that high doses of inhaled glucocorticoids may be associated with increased fracture risk, although concurrent use of oral glucocorticoids is often a confounding factor [11-14]. In a large case control study from Denmark, no increase in fracture risk was found in association with other forms of topical steroids [15].

Variation in the severity of adverse effects of glucocorticoids, including bone loss, is well recognized but poorly understood. Pre-receptor modulation of glucocorticoid activity by 11 beta-hydroxysteroid dehydrogenase (11ßHSD) enzymes, which interconvert inactive and active cortisone/cortisol, may contribute to this variability through the effects of pro-inflammatory cytokines $[16,17]$ and genetic polymorphisms in the glucocorticoid receptor gene [18].

\section{Pathophysiology}

\section{Direct effects on bone}

Glucocorticoid-induced osteoporosis is characterized by decreased bone formation, with an additional early but transient increase in bone resorption (Fig. 1). The initial increase in remodeling rate is accompanied by reduced bone formation at the level of the individual bone multicellular unit (BMU), and this combination of increased bone turnover and a negative remodeling balance results in rapid bone loss [19-23]. Subsequently, the decrease in bone formation, both at tissue and BMU level, predominates leading to a low turnover state. Direct effects of glucocorticoids on bone formation are mediated largely through upregulation of peroxisome proliferator-activated receptor gamma receptor 2 (PPAR $\gamma 2$ ) [24] and effects on the Wnt/ $/$ catenin signaling pathway $[25,26]$. The former mechanism favors the differentiation of pluripotent precursor cells to adipocytes in preference to osteoblasts, resulting in decreased numbers of osteoblasts. Increased expression of sclerostin, which binds to the co-receptors for frizzled, Lrp4 and Lrp5, results in inhibition of Wnt sigalling leading to reduced differentiation of osteoblast precursors to mature osteoblasts and increased osteoblast and osteocyte apoptosis. The importance of sclerostin in mediating the effects of glucocorticoids on bone formation is emphasized by the demonstration, in mice with sclerostin deficiency, that bone integrity is maintained in the presence of glucocorticoid excess [27]. Furthermore, in a mouse model of glucocorticoid-induced osteoporosis, treatment with an antibody to sclerostin prevented the reduction in bone mass and strength [28].

Glucocorticoids also have direct effects on bone resorption, increasing the production of macrophage colony stimulating factor (M-CSF) and RANKL and decreasing production of osteoprotegerin (OPG) by osteoblastic cells and osteocytes, resulting in an increase both in the number and activity of osteoclasts $[29,30]$. This effect diminishes with time, possibly as a result of the reduction in number of osteoblasts and osteocytes. Finally, there is some evidence from animal models that glucocorticoids affect osteocyte morphology and mineralization [31].

\section{Indirect effects on bone}

Other mechanisms that may contribute to glucocorticoidinduced bone loss through indirect effects on bone include hypogonadism, reduced physical activity, increased renal and intestinal losses of calcium, and reduced production of growth hormone, insulin-like growth factor 1 (IGF1) and IGF1 binding protein (IGF-BP) [32]. In addition, the underlying diseases for which glucocorticoid therapy is administered are often associated with increased inflammation, which contributes to bone loss through increased production of pro-inflammatory, pro-resorptive cytokines. Whilst glucocorticoids suppress inflammation and hence should mitigate the adverse effects of inflammation, disease relapse despite therapy is associated with episodes of increased bone resorption. Finally, glucocorticoid excess has adverse effects on muscle mass and function, leading to myopathy and increased risk of falls [33].

\section{Changes in BMD and bone microarchitecture}

Increased rates of bone loss in the hip, spine, and radius are well documented in individuals treated with glucocorticoids. Data obtained from assessment of bone microarchitecture using high-resolution peripheral computed tomography (HRpQCT) are sparse. In a cross-sectional study of 30 postmenopausal women who had received oral glucocorticoids for longer than 3 months, despite similar 


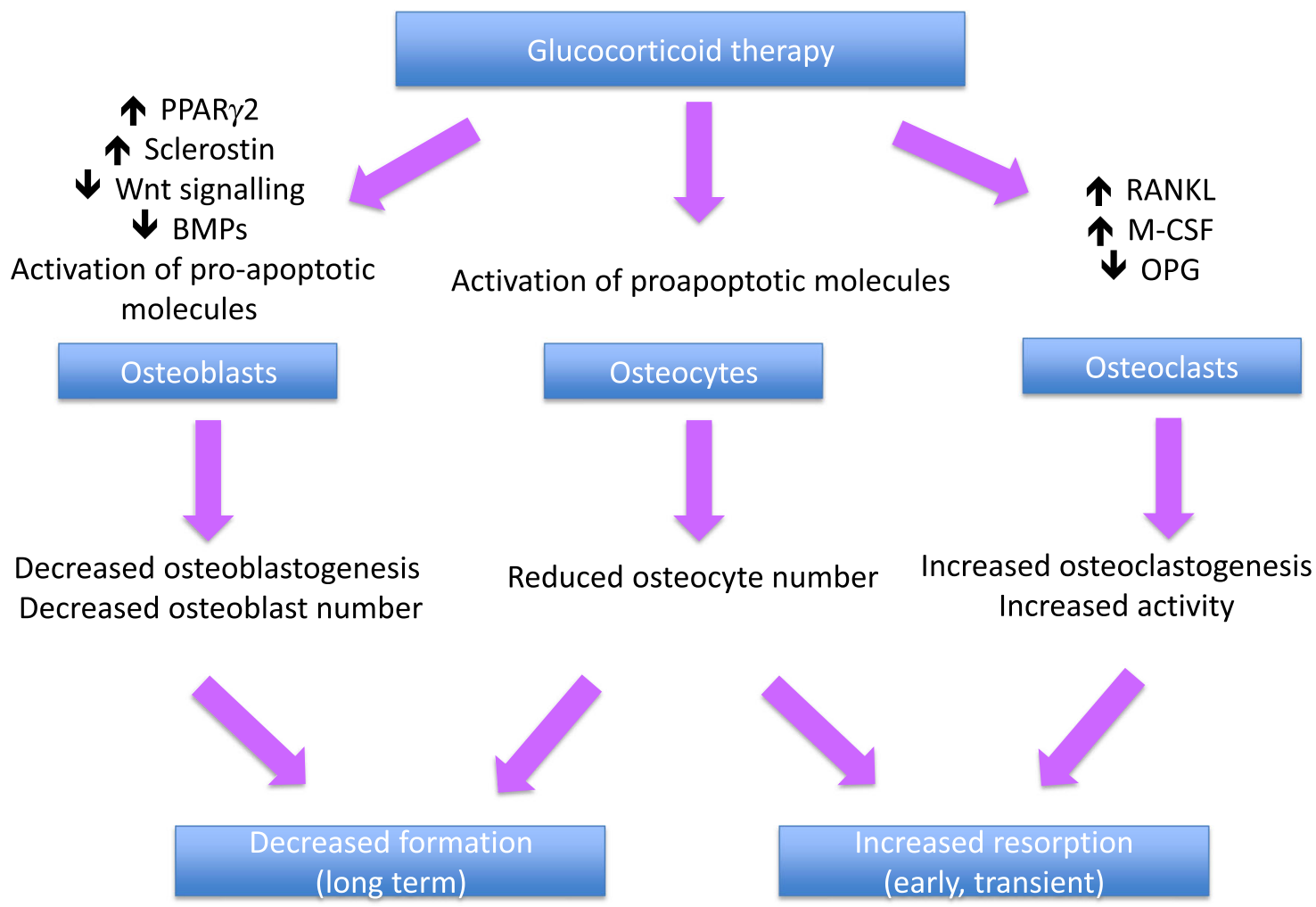

Fig. 1 Direct effects of glucocorticoids on bone

areal BMD values to 60 control subjects, significantly lower total, cortical and trabecular volumetric BMD, thinner cortices, increased trabecular separation and reduced trabecular number were reported in the radius and tibia; whole bone stiffness, assessed using finite element analysis, was also significantly reduced in comparison to the controls [34]. Although the patients and controls were generally well matched, however, bisphosphonate use was significantly more common in the former (100\% vs. $8.6 \%)$, so definite attribution of the observed differences to glucocorticoid therapy cannot be made.

Trabecular bone score (TBS) provides an indirect index of trabecular bone architecture that can be obtained from DXA images of the lumbar spine, and has predictive value for fracture independent of BMD [35]. In 64 postmenopausal women who had taken prednisolone in a dose of $\geq 5 \mathrm{mg}$ daily for $>3$ months, TBS was significantly lower than in a group of non-glucocorticoid treated controls, although lumbar spine BMD $T$-scores were not significantly different [36]. Similar findings have been reported in 416 individuals on long-term glucocorticoids ( $\geq 5 \mathrm{mg}$ daily for 3 months), the decrease in TBS being most marked in men and in individuals with fracture [37]. These findings indicate that glucocorticoids have adverse effects on spine bone microarchitecture that are independent of BMD and which may contribute to increased fracture risk.

\section{Fracture risk assessment in individuals treated with glucocorticoid-induced osteoporosis}

There is evidence from a number of studies that fracture occurs at a higher BMD in individuals receiving glucocorticoids than in non-glucocorticoid treated people [38-40]. This independent effect of glucocorticoid therapy on fracture risk may be due to several factors, including increased falls risk and alterations in bone quality that are not captured by BMD measurements.

Glucocorticoid therapy is included as a risk factor in the FRAX fracture prediction algorithm as a dichotomous variable. "Yes" is entered in the questionnaire if there is current exposure to oral glucocorticoids or past exposure for $\geq 3$ months at a dose of $5 \mathrm{mg} /$ day or more of prednisolone or equivalent. Using data from the UK General Research Practice Database, Kanis et al have provided adjustments that can be incorporated into the FRAX calculations to adjust for different doses of glucocorticoids (Table 1) [41]. For daily doses of over $7.5 \mathrm{mg}$ daily of prednisolone or equivalent, greater upward adjustment of fracture probability may be required. It should be noted that the duration of glucocorticoid therapy and cumulative dose are not accommodated within the FRAX algorithm. In addition, the use of total hip BMD in FRAX may result in underestimation of fracture risk in patients with differentially low 
Table 1 Adjustment of FRAX-derived fracture probability according to dose of glucocorticoids. Data from ref. [40]

\begin{tabular}{lll}
\hline $\begin{array}{l}\text { Daily dose of } \\
\text { prednisolone }(\mathrm{mg})\end{array}$ & $\begin{array}{l}\text { Average adjustment for } \\
\text { major osteoporotic } \\
\text { fracture probability }\end{array}$ & $\begin{array}{l}\text { Average adjustment } \\
\text { for hip fracture } \\
\text { probability }\end{array}$ \\
\hline$<2.5$ & $-20 \%$ & $-35 \%$ \\
$2.5-7.5$ & None & None \\
$\geq 7.5^{\mathrm{a}}$ & $+15 \%$ & $+20^{\mathrm{a}}$ \\
\hline
\end{tabular}

${ }^{a}$ For high doses of prednisolone, greater upward adjustment of fracture risk may be appropriate

spine BMD, although a correction for this discordance has been proposed $[42,43]$. A final caveat is that the response to treatment in glucocorticoid-treated individuals selected on the basis of FRAX-derived fracture probability has not been documented.

Assessment of fracture risk using FRAX is recommended in several guidelines for the management of glucocorticoid-induced osteoporosis, including the National Osteoporosis Guideline Group (NOGG) guidance [44, 45], the updated recommendations produced by the American College of Rheumatology (ACR) [46] and guidelines published by the International Osteoporosis Foundation (IOF) and European Calcified Tissues Society (ECTS) [47, 48]. However, FRAX can only be used in people age 40 years and over; in children and young adults, fracture risk assessment should be performed using BMD measurement, together with consideration of other risk factors, particularly previous fracture.

\section{Management of glucocorticoid-induced osteoporosis}

Under-treatment of glucocorticoid-induced osteoporosis is widely recognized $[49,50]$. In a population-based study of adults age $\geq 20$ years, rates of BMD testing and prescription of bone protective medication between 1998 and 2008 were studied in individuals prescribed systemic glucocorticoids for 90 days or longer [51]. Overall, in the first six months after initiation of glucocorticoid therapy only $6 \%$ had BMD testing, 22\% received therapy and $25 \%$ had both interventions. Under-treatment was greatest in younger people and men, and primary care physicians had lower prescription rates than rheumatologists. Similar results have been reported more recently using information from a national public health-insurance database in France, with only $8 \%$ undergoing BMD testing and prescription of calcium \pm vitamin $\mathrm{D}$ and bisphosphonates in 18 and $12 \%$ respectively [52]. In a large cohort from Canada of men and women aged 66 years or over who were initiating long-term glucocorticoid therapy, Amiche et al reported that only 13\% were prescribed bone protective therapy [53]. The problem of under-treatment is compounded by poor persistence with bisphosphonate therapy, particularly in younger people, those with co-morbidities, and those in whom BMD measurements have not been made [54].

\section{General measures}

A number of life-style measures may mitigate the harmful skeletal effects of glucocorticoids, although the evidence base for this approach is weak and requires extrapolation from studies in non-glucocorticoid treated individuals. Falls risk should be assessed and preventive measures instituted when appropriate. Exercise, tailored to the individual patient, and good nutrition with adequate dietary calcium intake should be advocated with avoidance of smoking and alcohol abuse. Maintenance of an adequate vitamin D status should also be advised.

Attention should be paid to keeping the dose of glucocorticoids to a minimum, with the use of steroid-sparing drugs such as methotrexate or azathioprine or alternative routes of administration (for example inhaled or topical) where appropriate. Non-steroidal therapies should be used when possible to maintain remission, once achieved. However, it is also important to maintain suppression of the underlying disease, since this will prevent the adverse skeletal effects of inflammation and other effects of increased disease activity.

Studies of the effects of calcium and/or vitamin D supplementation on BMD in patients taking glucocorticoids have produced conflicting results $[55,56]$. However, calcium and vitamin D supplements have been included in most trials of bone protective therapy and should therefore be used as an adjunct to treatment.

\section{Pharmacological interventions}

Regulatory approval of drugs to reduce fracture risk in individuals taking glucocorticoids has been based on the demonstration of similar changes in BMD to those observed in postmenopausal osteoporosis and fracture has been a secondary outcome. For this reason, evidence for anti-fracture efficacy of bone protective agents in glucocorticoid-induced osteoporosis is less robust than that for postmenopausal osteoporosis. In addition, there is inevitable heterogeneity in glucocorticoid-treated trial populations, with respect to age, underlying disease, co-morbidities and co-medications, dose and duration of glucocorticoid therapy and the timing of bone protective therapy. Furthermore, the duration of most treatment studies has been relatively short and this, combined with smaller trial populations, reduces the strength of the safety database. 


\section{Bisphosphonates}

Bisphosphonates are the most commonly used drugs in the management of glucocorticoid-induced osteoporosis. Oral alendronate ( 5 or $10 \mathrm{mg}$ daily or $70 \mathrm{mg}$ once weekly) and risedronate ( $5 \mathrm{mg}$ daily or $35 \mathrm{mg}$ once weekly), and intravenous zoledronic acid ( $5 \mathrm{mg}$ once yearly by intravenous infusion) are all approved for this indication. All have been shown to have beneficial effects on lumbar spine and hip BMD in people treated with glucocorticoids [57-64] and for alendronate and risedronate, there is also evidence from safety or post hoc analyses for a reduction in the rate of vertebral fractures [62, 63]. In the pivotal study of zoledronic acid, a non-inferiority BMD comparison with risedronate, the fracture rate was too low to assess anti-fracture efficacy [64].

The number of non-vertebral and hip fractures has been insufficient in individual trials to assess an impact of bisphosphonates. However, data from cohort studies provide some evidence for efficacy at these sites. In an observational cohort study of women aged $>65$ years taking alendronate or risedronate, Thomas et al. studied the baseline incidence of clinical fractures in the first three months after starting glucocorticoid therapy and the fracture incidence in the following 12 months [65]. Compared to the baseline incidence, both clinical vertebral and non-vertebral fracture incidence were significantly lower. Using the same database, Overton et al studied the effects of bone protective therapy (bisphosphonates in $95.5 \%$, denosumab or teriparatide in the remaining $4.5 \%$ ) in a large cohort of new glucocorticoid users [66]. Treatment within the first 90 days of glucocorticoid use was associated with a significant reduction in clinical fractures (including vertebral) of $48 \%$ at one year and $32 \%$ at three years when compared with non-use. Finally, in three matched cohorts derived from healthcare administrative data from Ontario, Canada, Amiche et al. reported that in individuals initiating long-term glucocorticoids, therapy within the first six months with alendronate or risedronate was associated with a decrease in incident hip fracture (alendronate $0.49(0.34,0.69)$, risedronate 0.58 $(0.36,0.90)[53]$. The results confirmed a reduction in vertebral fracture risk with etidronate, alendronate and risedronate, but no decrease in risk of forearm or humerus fractures for any bisphosphonate. The analysis was limited to oral bisphosphonates and zoledronic acid was not considered. Overall, therefore, these studies would be consistent with a beneficial effect of bisphosphonates both on vertebral and non-vertebral fracture, including hip fracture.

The safety profile of bisphosphonates in glucocorticoidinduced osteoporosis has been less well studied than in postmenopausal osteoporosis because of the small number of participants included and shorter duration of the trials. Because of co-morbidities and co-medications, people taking glucocorticoids may be more susceptible to sideeffects, for example upper gastrointestinal disorders, and glucocorticoid therapy is a documented risk factor for osteonecrosis of the jaw [67] and probably also for atypical femoral fractures $[68,69]$. Bisphosphonates should be used with caution in premenopausal women with child bearing potential, because of the ability of these drugs to cross the placenta.

\section{Teriparatide}

The predominant role of reduced bone formation in glucocorticoid-induced osteoporosis provides a rationale for the use of anabolic agents in its treatment. In an activecomparator controlled, randomized, double blind study the effects of 18 months treatment with subcutaneous teriparatide, $20 \mu \mathrm{g} / \mathrm{day}$, or oral alendronate $10 \mathrm{mg} / \mathrm{day}$, were compared in 428 men and women with glucocorticoid-induced osteoporosis [70]. Teriparatide therapy resulted in significantly greater increases in spine and hip BMD and this was seen in both premenopausal and postmenopausal women and in men [71]. The magnitude of increase in BMD was somewhat less than that seen in nonglucocorticoid treated postmenopausal women in another study [72], possibly as a result of the opposing actions of intermittent PTH and glucocorticoids on osteoblastogenesis, and osteoblast and osteocyte apoptosis [73-75].

Although fracture was not a primary end-point of the study, significantly fewer new vertebral fractures occurred in the patients treated with teriparatide when compared to those treated with alendronate $(0.6 \%$ vs. $6.1 \% ; p=0.004)$. The incidence of non-vertebral fractures was similar in the two treatment groups. Results after 36 months of treatment demonstrated a continued increase in spine and hip BMD in the teriparatide treated group, with superiority over alendronate at the 24 and 36 month time points [76]. A lower incidence of new vertebral fractures was also seen in the teriparatide group at 36 months $(1.7 \%$ vs $7.7 \%, p=0.007)$, with a similar incidence of non-vertebral fractures in the two groups. Interestingly, measurements of TBS in a subpopulation of this study demonstrated a significant increase after 36 months in teriparatide treated patients, but no significant change in those treated with alendronate [77].

Whilst the long duration of this study is unique amongst treatment trials for glucocorticoid-induced osteoporosis, it should be noted that the participant discontinuation rate at 36 months was $44 \%$. With regard to safety, increased predose serum calcium levels were significantly more common in the teriparatide than alendronate treated group (21\% vs. $7 \%$ ), but no other concerns were identified

In a comparison of the effects of teriparatide and risedronate in men treated with oral glucocorticoids for $\geq 3$ months, significantly greater increases in lumbar spine 
trabecular volumetric BMD were demonstrated in the teriparatide-treated group at 18 months. In addition, teriparatide was associated with significantly greater improvements in bone strength and stiffness at T12, measured using HRQCT-based finite element analysis [78]. These data, together with the results of the study reviewed above, provide a rationale for the use of teriparatide as a first line option in some patients, particularly those at high risk of vertebral fracture.

Teriparatide is contraindicated in pregnant and lactating women. Women of childbearing potential should use effective methods of contraception while on teriparatide treatment.

\section{Denosumab}

At present, denosumab is not approved for use in glucocorticoid-induced osteoporosis, although this is currently under consideration by some regulatory agencies. In a Phase 3 randomized double blind active controlled trial of adults taking $\geq 7.5 \mathrm{mg}$ prednisone or equivalent daily, treatment with denosumab, $60 \mathrm{mg}$ once every 6 months by subcutaneous injection, was associated with a significantly greater increase in lumbar spine BMD compared to risedronate $5 \mathrm{mg}$ daily over a 12 months treatment period [79]. This effect was seen both in patients initiating glucocorticoids and in those established on long-term therapy, regardless of age, race, baseline BMD $T$-score, initial glucocorticoid dose and menopausal status. To date the study has only been reported in abstract form.

\section{Guidelines for the management of glucocorticoid- induced osteoporosis}

National guidelines for the management of glucocorticoidinduced osteoporosis have been produced by a number of countries and updated guidelines have recently been published from the US and UK. Most guidelines address users of long-term (3 months) oral glucocorticoids, and although the daily threshold dose varies it has generally been between 5 and $7.5 \mathrm{mg}$ daily of prednisolone or equivalent. Treatment thresholds also vary; $T$-scores are used in some and generally recognize the higher BMD at which fracture occurs in glucocorticoid-treated individuals. The recent guidelines from the UK and US emphasize the importance of starting bone protective therapy early in high-risk individuals, because of the rapidity with which bone loss and increased fracture risk occur.

The recently updated ACR guideline defines three categories of fracture risk; high, moderate and low. In adults aged $\geq 40$ years, previous osteoporotic fracture, hip or spine
BMD $T$-score $\leq-2.5$, or 10 year fracture probability of $\geq 20 \%$ (major osteoporotic fracture) or $\geq 3 \%$ (hip fracture) are the criteria for high risk [45]. Moderate and low risk are defined solely on the basis of FRAX-derived fracture probability $(10-19 \%$ and $>1$ to $\leq 3 \%$ respectively for moderate risk, $<10 \%$ and $\leq 1 \%$ respectively for low risk). In adults $<40$ years old, the criterion for high risk is a previous osteoporotic fracture, whereas moderate and low risk are defined on the basis of BMD. Oral bisphosphonates are recommended as the first line option for individuals at moderate or high risk, with intravenous bisphosphonates, teriparatide, or denosumab in patients who are contraindicated or intolerant to oral bisphosphonates. NOGG, in its 2017 update, takes a similar approach to risk assessment with the use of dose-adjusted FRAX, but uses the UK NOGG intervention thresholds as the basis for making treatment decisions and does not include denosumab as a treatment option [44, 45].

These recent guidelines emphasize the importance of early intervention in high-risk individuals, advocate maintenance of adequate calcium intake and normal vitamin D status, and stress the limited evidence base to support some recommendations, particularly in younger adults. Comparison of the cost-effectiveness of different treatments is problematic because of the lack of fracture data, particularly hip fracture, in clinical trials. The choice of oral bisphosphonates as a first line option in both sets of guidelines is based on their lower cost compared to either zoledronic acid or teriparatide; nevertheless, in view of the superiority of teriparatide vs. alendronate for BMD and vertebral fracture outcomes, it has been suggested that teriparatide should be considered as an alternative first line option in those at highest risk [80].

\section{Conclusions}

There have been significant advances in our understanding of the mechanisms by which glucocorticoids affect bone and increase fracture risk. The clinical management of glucocorticoid-induced osteoporosis, however, remains suboptimal despite the development of more sophisticated approaches to fracture risk assessment and the availability of several effective treatment options. Whilst bisphosphonates are currently the most widely used bone protective drugs in individuals taking glucocorticoids, the use of teriparatide and of denosumab (if approved) as first-line options in some patients merits further investigation. Finally, the potential for sclerostin inhibitors to prevent or reverse adverse skeletal effects of glucocorticoids provides an exciting prospect for future research. 


\section{Compliance with ethical standards}

Conflict of interest Prof Compston has received advisory and speaking fees from Gilead and speaking fees from Amgen and UCB.

Open Access This article is distributed under the terms of the Creative Commons Attribution 4.0 International License (http://crea tivecommons.org/licenses/by/4.0/), which permits unrestricted use, distribution, and reproduction in any medium, provided you give appropriate credit to the original author(s) and the source, provide a link to the Creative Commons license, and indicate if changes were made.

\section{References}

1. T.P. van Staa, H.G. Leufkens, L. Abenhaim, S. Begaud, B. Zhang, C. Cooper, Use of oral corticosteroids in the United Kingdom. Q Med J. 93, 105-111 (2000)

2. L. Fardet, I. Petersen, I. Nazareth, Prevalence of long-term oral glucocorticoid prescriptions in the UK over the past 20 years. Rheumatology 50(11), 1982-1990 (2011)

3. R.A. Overman, J.Y. Yeh, C.L. Deal, Prevalence of oral glucocorticoid usage in the United States: a general population perspective. Arthritis Care Res. 65(2), 294-298 (2013)

4. S. Silverman, J. Curtis, K. Saag, J. Flahive, J. Adachi, F. Anderson, R. Chapurlat, C. Cooper, A. Diez-Perez, S. Greenspan, F. Hooven, A. Le Croix, L. March, J.C. Netelenbos, J. Nieves, J. Pfeilschifter, M. Rossini, C. Roux, E. Siris, N. Watts, J. Compston, International management of bone health in glucocorticoidexposed individuals in the observational GLOW study. Osteoporos. Int. 26(1), 419-420 (2015)

5. T. van Staa, H.G.M. Leufkens, L. Abenhaim, B. Zhang, C. Cooper, Use of oral corticosteroids and risk of fractures. J. Bone Miner. Res. 15, 933-1000 (2000)

6. F. De Vries, M. Bracke, H.G. Leufkens, J.W. Lammers, C. Cooper, T.P. Van Staa, Fracture risk with intermittent high-dose glucocorticoid therapy. Arthritis Rheum. 56, 206-214 (2007)

7. T.P. van Staa, H.G.M. Leufkens, L. Abenhaim, B. Zhang, C. Cooper, Oral corticosteroids and fracture risk: relationship to daily and cumulative doses. Rheumatology 39, 1383-1389 (2000)

8. T.P. van Staa, H.G.M. Leufkens, C. Cooper, A meta-analysis of the epidemiology of corticosteroid-induced osteoporosis. Osteoporos. Int. 13, 777-787 (2002)

9. M.A. Amiche, J.M. Albaum, M. Tadrous, P. Pechlivanoglou, L.E. Lévesque, J.D. Adachi, S.M. Cadarette, Fracture risk in oral glucocorticoid users: a Bayesian meta-regression leveraging control arms of osteoporosis clinical trials. Osteoporos. Int. 27(5), 1709-1718 (2016)

10. A. Balasubramanian, S.W. Wade, R.A. Adler, C.J.F. Lin, M. Maricic, C.D. O’Malley, K. Saag, J.R. Curtis, Glucocorticoid exposure and fracture risk in patients with new-onset rheumatoid arthritis. Osteoporos. Int. 27(11), 3239-3249 (2016)

11. J.H. Toogood, J.C. Baskerville, A.E. Markov, A.B. Hodsman, L.J. Fraher, B. Jennings, R.G. Haddad, D. Drost, Bone mineral density and the risk of fractures in patients receiving long-term inhaled steroid therapy for asthma. J. Allergy Clin. Immunol. 96, 157-166 (1995)

12. C.A. Wong, L.J. Walsh, C.J. Smith, A.F. Wisniewski, S.A. Lewis, R. Hubbard, S. Cawte, D.J. Green, M. Pringle, A.E. Tattersfield, Inhaled corticosteroid use and bone mineral density in patients with asthma. Lancet 355, 1399-1403 (2000)
13. T.P. Van Staa, H.G. Leufkens, C. Cooper, Use of inhaled corticosteroids and risk of fractures. J. Bone Miner. Res. 16, 581-588 (2001)

14. T.P. Van Staa, N. Bishop, H.G. Leufkens, C. Cooper, Are inhaled corticosteroids associated with an increased risk of fracture in children? Osteoporos. Int. 15, 785-791 (2004)

15. P. Vestergaard, L. Rejnmark, L. Mosekilde, Fracture risk associated with systemic and topical corticosteroids. J. Intern. Med. 257(4), 374-84 (2005)

16. M.S. Cooper, A. Blumsohn, P.E. Goddard, W.A. Bartlett, C.H. Shackleton, R. Eastell, M. Hewison, P.M. Stewart, 11 betahydroxysteroid dehydrogenase type 1 activity predicts the effects of glucocorticoids on bone. J. Clin. Endocrinol. Metab. 83, 3874-3877 (2003)

17. M.S. Cooper, I. Bujalska, E. Rabbitt, E.A. Walker, R. Bland, M.C. Sheppard, M. Hewison, Stewart PM.Modulation of 11-beta hydroxysteroid dehydrogenase enzymes by proinflammatory cytokines in osteoblasts: an autocrine switch from glucocorticoid inactivation to activation. J. Bone Miner. Res. 16, 1037-1044 (2001)

18. H. Russcher, P. Smit, E.L.T. van den Akker, E.F. van Rossum, A. O. Brinkmann, F.H. de Jong, S.W. Lamberts, J.W. Koper, Two polymorphisms in the glucocorticoid receptor gene directly affect glucocorticoid-regulated gene expression. J. Clin. Endocrinol. Metab. 90, 5804-5810 (2005)

19. C. Bresssot, P.J. Meunier, M.C. Chapuy, E. Lejeune, C. Edouard, A.J. Darby, Histomorphometric profile, pathophysiology and reversibility of corticosteroid-induced osteoporosis. Metab. Bone Dis. Rel. Res. 1, 303-311 (1979)

20. D.W. Dempster, M.A. Arlot, P.J. Meunier, Mean wall thickness and formation periods of trabecular bone packets in corticosteroid-induced osteoporosis. Calcif. Tissue Int. 35, 410-417 (1983)

21. D.W. Dempster, Bone histomorphometry in glucocorticoidinduced osteoporosis. J. Bone Miner. Res. 4, 137-147 (1989)

22. D. Chappard, E. Legrand, M.F. Basle, P. Fromont, J.L. Racineux, A. Rebel, M. Audran, Altered trabecular architecture induced by corticosteroids: a bone histomorphometric study. J. Bone Miner. Res. 11, 676-685 (1996)

23. L. Dalle Carbonare, M.E. Arlot, P.M. Chavassieux, J.P. Roux, N.R. Portero, P.J. Meunier, Comparison of trabecular bone architecture and remodeling in glucocorticoid-induced and postmenopausal osteoporosis. J. Bone Miner. Res. 16, 97-103 (2001)

24. Z. Wu, N.L.R. Bucher, S.R. Farmer, Induction of peroxisome proliferator-activated receptor $\gamma$ during the conversion of 3T3 fibroblasts into adipocytes is mediated by $\mathrm{C} / \mathrm{EBPh}, \mathrm{C} / \mathrm{EBPy}$, and glucocorticoids. Mol. Cell. Biol. 16, 4128-4136 (1996)

25. R.S. Weinstein, R.L. Jilka, A.M. Parfitt, S.C. Manolagas, Inhibition of osteoblastogenesis and promotion of apoptosis of osteoblasts and osteocytes by glucocorticoids-potential mechanisms of their deleterious effects on bone. J. Clin. Invest. 102, 274-282 (1998)

26. K. Ohnaka, M. Tanabe, H. Kawate, H. Nawata, R. Takayanagi, Glucocorticoid suppresses the canonical Wnt signal in cultured human osteoblasts. Biochem. Biophys. Res. Commun. 329, 177-181 (2005)

27. A.Y. Sato, M. Cregor, J. Delgado-Calle, K.W. Condon, M.R. Allen, M. Peacock, L.I. Plotkin, T. Bellido, Protection from glucocorticoid-induced osteoporosis by anti-catabolic signaling in the absence of sost/sclerostin. J. Bone Miner. Res. 31, 1791-1802 (2016)

28. W. Yao, W. Dai, L. Jiang, E.Y. Lay, Z. Zhong, R.O. Ritchie, X. Li, H. Ke, N.E. Lane, Sclerostin-antibody treatment of glucocorticoid-induced osteoporosis maintained bone mass and strength. Osteoporos. Int. 27(1), 283-294 (2016) 
29. C. Swanson, M. Lorentzon, H.H. Conaway, U.H. Lerner, Glucocorticoid regulation of osteoclast differentiation and expression of receptor activator of nuclear factor-kappaB (NF-kappaB) ligand, osteoprotegerin, and receptor activator of NF-kappaB in mouse calvarial bones. Endocrinology 147(7), 3613-3622 (2006)

30. L.C. Hofbauer, F. Gori, B.L. Riggs, D.L. Lacey, C.R. Dunstan, T. C. Spelsberg, S. Khosla, Stimulation of osteoprotegerin ligand and inhibition of osteoprotegerin production by glucocorticoids in human osteoblasts: potential paracrine mechanisms of glucocorticoid-induced osteoporosis. Endocrinology 140, 4382-4389 (1999)

31. N.E. Lane, W. Yao, M. Balooch, R.K. Nalla, G. Balooch, S. Habelitz, J.H. Kinney, L.F. Bonewald, Glucocorticoid-treated mice have localized changes in trabecular bone material properties and osteocyte lacunar size that are not observed in placebo-treated or oestrogen-deficient mice. J. Bone Miner. Res. 21, 466-476 (2006)

32. G. Mazziotti, A.M. Formenti, R.A. Adler, J.P. Bilezikian, A. Grossman, E. Sbardella, S. Minisola, A. Giustina, Glucocorticoidinduced osteoporosis: pathophysiological role of GH/IGF-I and PTH/VITAMIN D axes, treatment options and guidelines. Endocrine 54(3), 603-611 (2016)

33. A.Y. Sato, D. Richardson, M. Cregor, H.M. Davis, E.D. Au, K. McAndrews, T.A. Zimmers, J.M. Organ, M. Peacock, L.I. Plotkin, T. Bellido, Glucocorticoids induce bone and muscle atrophy by tissue-specific mechanisms upstream of E3 ubiquitin ligases. Endocrinology 158(3), 664-677 (2017)

34. S. Sutter, K.K. Nishiyama, A. Kepley, B. Zhou, J. Wang, D.J. McMahon, X.E. Guo, E.M. Stein, Abnormalities in cortical bone, trabecular plates, and stiffness in postmenopausal women treated with glucocorticoids. J. Clin. Endocrinol. Metab. 99(11), 4231-40 (2014)

35. E.V. McCloskey, A. Odén, N.C. Harvey, W.D. Leslie, D. Hans, H. Johansson, R. Barkmann, S. Boutroy, J. Brown, R. Chapurlat, P.J. Elders, Y. Fujita, C.C. Glüer, D. Goltzman, M. Iki, M. Karlsson, A. Kindmark, M. Kotowicz, N. Kurumatani, T. Kwok, O. Lamy, J. Leung, K. Lippuner, Ö. Ljunggren, M. Lorentzon, D. Mellström, T. Merlijn, L. Oei, C. Ohlsson, J.A. Pasco, F. Rivadeneira, B. Rosengren, E. Sornay-Rendu, P. Szulc, J. Tamaki, J.A. Kanis, A meta-analysis of trabecular bone score in fracture risk prediction and its relationship to FRAX. J. Bone Miner. Res. 31 (5), 940-948 (2016).

36. M.A. Paggiosi, N.F. Peel, R. Eastell, The impact of glucocorticoid therapy on trabecular bone score in older women. Osteoporos. Int. 26(6), 1773-1780 (2015)

37. K.G. Saag, D. Agnusdei, D. Hans, L.A. Kohlmeier, K.D. Krohn, E.S. Leib, E.J. MacLaughlin, J. Alam, C. Simonelli, K.A. Taylor, R. Marcus, Trabecular bone score in patients with chronic glucocorticoid therapy-induced osteoporosis treated With alendronate or teriparatide. Arthritis Rheumatol. 68(9), 2122-2128 (2016)

38. M. Luengo, C. Picado, L. Del Rio, N. Guañabens, J.M. Montserrat, J. Setoain, Vertebral fractures in steroid dependent asthma and involutional osteoporosis: a comparative study. Thorax 46 (11), 803-806 (1991)

39. T.P. van Staa, R.F. Laan, I.P. Barton, S. Cohen, D.M. Reid, C. Cooper, Bone density threshold and other predictors of vertebral fracture in patients receiving oral glucocorticoid therapy. Arthritis Rheum. 48, 3224-3229 (2003)

40. J.A. Kanis, H. Johansson, A. Oden, O. Johnell, C. de Laet, L.J. Melton III, A. Tenenhouse, J. Reeve, A.J. Silman, H.A. Pols, J.A. Eisman, E.V. McCloskey, D. Mellstrom, A meta-analysis of prior corticosteroid use and fracture risk. J. Bone Miner. Res. 19, 893-899 (2004)

41. J.A. Kanis, H. Johansson, A. Oden, E.V. McCloskey, Guidance for the adjustment of FRAX according to the dose of glucocorticoids. Osteoporos. Int. 22(3), 809-816 (2011)
42. W.D. Leslie, L.M. Lix, H. Johansson, A. Oden, E. McCloskey, J. A. Kanis, Spine-hip discordance and fracture risk assessment: a physician-friendly FRAX enhancement. Osteoporos. Int. 22(3), 839-847 (2011)

43. H. Johansson, J.A. Kanis, A. Odén, W.D. Leslie, S. Fujiwara, C. C. Glüer, H. Kroger, A.Z. LaCroix, E. Lau, L.J. Melton 3rd, J.A. Eisman, T.W. O'Neill, D. Goltzman, D.M. Reid, E. McCloskey, Impact of femoral neck and lumbar spine BMD discordances on FRAX probabilities in women: a meta-analysis of international cohorts. Calcif. Tissue Int. 95(5), 428-435 (2014)

44. J. Compston, A. Cooper, C. Cooper, N. Gittoes, C. Gregson, N. Harvey, S. Hope, J.A. Kanis, E.V. McCloskey, K.E.S. Poole, D. M. Reid, P. Selby, F. Thompson, A. Thurston, N. Vine; National Osteoporosis Guideline Group (NOGG), UK clinical guideline for the prevention and treatment of osteoporosis. Arch. Osteoporos. 12(1), 43 (2017)

45. National Osteoporosis Guideline Group: clinical guideline for the prevention and treatment of osteoporosis. https://www.sheffield. ac.uk/NOGG/ (2017)

46. L. Buckley, G. Guyatt, H.A. Fink, M. Cannon, J. Grossman, K.E. Hansen, M.B. Humphrey, N.E. Lane, M. Magrey, M. Miller, L. Morrison, M. Rao, A. Byun Robinson, S. Saha, S. Wolver, R.R. Bannuru, E. Vaysbrot, M. Osani, M. Turgunbaev, A.S. Miller, T. McAlindon, American college of rheumatology guideline for the prevention and treatment of glucocorticoid-induced osteoporosis. Arthritis Care Res. 69(8), 1095-1110 (2017)

47. S. Lekamwasam, J.D. Adachi, D. Agnusdei, J. Bilezikian, S. Boonen, F. Borgström, C. Cooper, A. Diez Perez, R. Eastell, L.C. Hofbauer, J.A. Kanis, B.L. Langdahl, O. Lesnyak, R. Lorenc, E. McCloskey, O.D. Messina, N. Napoli, B. Obermayer-Pietsch, S. H. Ralston, P.N. Sambrook, S. Silverman, M. Sosa, J. Stepan, G. Suppan, D.A. Wahl, J.E. Compston; Joint IOF-ECTS GIO Guidelines Working Group, A framework for the development of guidelines for the management of glucocorticoid-induced osteoporosis. Osteoporos. Int. 23(9), 2257-2276 (2012)

48. S. Lekamwasam, J.D. Adachi, D. Agnusdei, J. Bilezikian, S. Boonen, F. Borgström, C. Cooper, A.D. Perez, R. Eastell, L.C. Hofbauer, J.A. Kanis, B.L. Langdahl, O. Lesnyak, R. Lorenc, E. McCloskey, O.D. Messina, N. Napoli, B. Obermayer-Pietsch, S. H. Ralston, P.N. Sambrook, S. Silverman, M. Sosa, J. Stepan, G. Suppan, D.A. Wahl, J.E. Compston; Joint IOF-ECTS GIO Guidelines Working Group, An appendix to the 2012 IOF-ECTS guidelines for the management of glucocorticoid-induced osteoporosis. Arch. Osteoporos. 7, 25-30 (2012)

49. J.R. Curtis, A.O. Westfall, J.J. Allison, A. Becker, L. Casebeer, A. Freeman, C.M. Spettell, N.W. Weissman, S. Wilke, K.G. Saag, Longitudinal patterns in the prevention of osteoporosis in glucocorticoid-treated patients. Arthritis Rheum. 52, 2485-2494 (2005)

50. A.C. Feldstein, P.J. Elmer, G.A. Nichols, M. Herson, Practice patterns in patients at risk for glucocorticoid-induced osteoporosis. Osteoporos. Int. 16, 2168-2174 (2005)

51. S.R. Majumdar, L.M. Lix, S.N. Morin, M. Yogendran, C.J. Metge, W.D. Leslie, The disconnect between better quality of glucocorticoid-induced osteoporosis preventive care and better outcomes: a population-based cohort study. J. Rheumatol. 40(10), 1736-1741 (2013)

52. S. Trijau, G. de Lamotte, V. Pradel, F. Natali, V. Allaria-Lapierre, H. Coudert, T. Pham, V. Sciortino, P. Lafforgue, Osteoporosis prevention among chronic glucocorticoid users: results from a public health insurance database. RMD Open 2, e000249 (2016)

53. M.A. Amiche, L.E. Lévesque, T. Gomes, J.D. Adachi, S.M. Cadarette, Effectiveness of oral bisphosphonates in reducing fracture risk among oral glucocorticoid users: three matched cohort analyses. J. Bone Miner. Res. 33, 419-429 (2017). https:// doi.org/10.1002/jbmr.3318. 
54. J.R. Curtis, A.O. Westfall, J.J. Allison, A. Freeman, K.G. Saag, Channeling and adherence with alendronate and risedronate among chronic glucocorticoid users. Osteoporos. Int. 17(8), 1268-1274 (2006)

55. L.M. Buckley, E.S. Leib, K.S. Cartularo, P.M. Vacek, S.M. Cooper, Calcium and vitamin D3 supplementation prevents bone loss in the spine secondary to low-dose corticosteroids in patients with rheumatoid arthritis. A randomized, double-blind, placebocontrolled trial. Ann. Intern. Med. 125(12), 961-968 (1996)

56. J.D. Adachi, W.G. Bensen, F. Bianchi, A. Cividino, S. Pillersdorf, R.J. Sebaldt, P. Tugwell, M. Gordon, M. Steele, C. Webber, C.H. Goldsmith, Vitamin D and calcium in the prevention of corticosteroid induced osteoporosis: a 3 year followup. J. Rheumatol. 23(6), 995-1000 (1996)

57. K.G. Saag, R. Emkey, T.J. Schnitzer, J.P. Brown, F. Hawkins, S. Goemaere, G. Thamsborg, U.A. Liberman, P.D. Delmas, M.P. Malice, M. Czachur, A.G. Daifotis, Alendronate for the prevention and treatment of glucocorticoid induced osteoporosis. Glucocorticoid-Induced Osteoporosis Intervention Study Group. N. Engl. J. Med. 339, 292-299 (1998)

58. J.D. Adachi, K.G. Saag, P.D. Delmas, U.A. Liberman, R.D. Emkey, E. Seeman, N.E. Lane, J.M. Kaufman, P.E. Poubelle, F. Hawkins, R. Correa-Rotter, C.J. Menkes, J.A. Rodriguez-Portales, T.J. Schnitzer, J.A. Block, J. Wing, H.H. Mcllwain, R. Westhovens, J. Brown, J.A. Melo-Gomes, B.L. Gruber, M.J. Yanover, M. O. Leite, K.G. Siminoski, M.C. Nevitt, J.T. Sharp, M.P. Malice, T. Dumortier, M. Czachur, W. Carofano, A. Daifotis, Two-year effects of alendronate on bone mineral density and vertebral fracture in patients receiving glucocorticoids: a randomized, double-blind, placebo-controlled extension trial. Arthritis Rheum. 44, 202-211 (2001)

59. S.A. Stoch, K.G. Saag, M. Greenwald, A.I. Sebba, S. Cohen, N. Verbruggen, H. Giezek, J. West, T.J. Schnitzer, Once-weekly oral alendronate $70 \mathrm{mg}$ in patients with glucocorticoid-induced bone loss: a 12-month randomized, placebo-controlled clinical trial. J. Rheumatol. 36, 1705-1714 (2009)

60. S. Cohen, R.M. Levy, M. Keller, E. Boling, R.D. Emkey, M. Greenwald, T.M. Zizic, S. Wallach, K.L. Sewell, B.P. Lukert, D. W. Axelrod, A.A. Chines, Risedronate therapy prevents corticosteroid-induced bone loss: a twelve-month, multicenter, randomized, double-blind, placebo-controlled, parallel group study. Arthritis Rheum. 42, 2309-2318 (1999)

61. D.M. Reid, R.A. Hughes, R.F. Laan, N.A. Sacco-Gibson, D.H. Wenderoth, S. Adami, R.A. Eusebio, J.P. Devogelaer, Efficacy and safety of daily risedronate in the treatment of corticosteroidinduced osteoporosis in men and women: a randomized trial. European Corticosteroid-Induced Osteoporosis Treatment Study. J. Bone Miner. Res. 15, 1006-1013 (2000)

62. S. Wallach, S. Cohen, D.M. Reid, R.A. Hughes, D.J. Hosking, R. F. Laan, S.M. Doherty, M. Maricic, C. Rosen, J. Brown, I. Barton, A.A. Chines, Effects of risedronate treatment on bone density and vertebral fracture in patients on corticosteroid therapy. Calcif. Tissue Int. 67, 277-285 (2000)

63. D.M. Reid, S. Adami, J.P. Devogelaer, A.A. Chines, Risedronate increases bone density and reduces vertebral fracture risk within one year in men on corticosteroid therapy. Calcif. Tissue Int. 69, 242-247 (2001)

64. D.M. Reid, J.P. Devogelaer, K. Saag, C. Roux, C.S. Lau, J.Y. Reginster, P. Papanastasiou, A. Ferreira, F. Hartl, T. Fashola, P. Mesenbrink, P.N. Sambrook, HORIZON investigators. Zoledronic acid and risedronate in the prevention and treatment of glucocorticoid-induced osteoporosis (HORIZON): a multicentre, double-blind, double-dummy, randomised controlled trial. Lancet 373, 1253-1263 (2009)

65. T. Thomas, S. Horlait, J.D. Ringe, A. Abelson, D.T. Gold, P. Atlan, J.L. Lange, Oral bisphosphonates reduce the risk of clinical fractures in glucocorticoid-induced osteoporosis in clinical practice. Osteoporos. Int. 24(1), 263-269 (2013)

66. R.A. Overman, M.L. Gourlay, C.L. Deal, J.F. Farley, M.A. Brookhart, J.B. Layton, Fracture rate associated with quality metric-based anti-osteoporosis treatment in glucocorticoidinduced osteoporosis. Osteoporos. Int. 26(5), 1515-1524 (2015)

67. A.A. Khan, A. Morrison, D.A. Hanley, D. Felsenberg, L.K. McCauley, F. O'Ryan, I.R. Reid, S.L. Ruggiero, A. Taguchi, S. Tetradis, N.B. Watts, M.L. Brandi, E. Peters, T. Guise, R. Eastell, A.M. Cheung, S.N. Morin, B. Masri, C. Cooper, S.L. Morgan, B. Obermayer-Pietsch, B.L. Langdahl, R. Al Dabagh, K.S. Davison, D.L. Kendler, G.K. Sándor, R.G. Josse, M. Bhandari, M. El Rabbany, D.D. Pierroz, R. Sulimani, D.P. Saunders, J.P. Brown, J. Compston, International Task Force on Osteonecrosis of the Jaw. Diagnosis and management of osteonecrosis of the jaw: a systematic review and international consensus. J. Bone Miner. Res. 30(1), 3-23 (2015)

68. E. Shane, D. Burr, B. Abrahamsen, R.A. Adler, T.D. Brown, A.M. Cheung, F. Cosman, J.R. Curtis, R. Dell, D.W. Dempster, P.R. Ebeling, T.A. Einhorn, H.K. Genant, P. Geusens, K. Klaushofer, J.M. Lane, F. McKiernan, R. McKinney, A. Ng, J. Nieves, R. O'Keefe, S. Papapoulos, T.S. Howe, M.C. van der Meulen, R.S. Weinstein, M.P. Whyte, Atypical subtrochanteric and diaphyseal femoral fractures: second report of a task force of the American Society for Bone and Mineral Research. J. Bone Miner. Res. 29 (1), 1-23 (2014)

69. J.H. Koh, J.P. Myong, J. Yoo, Y.W. Lim, J. Lee, S.K. Kwok, S.H. Park, J.H. Ju, Predisposing factors associated with atypical femur fracture among postmenopausal Korean women receiving bisphosphonate therapy: 8 years' experience in a single center. Osteoporos. Int. 28(11), 3251-3259 (2017)

70. K.G. Saag, E. Shane, S. Boonen, F. Marín, D.W. Donley, K.A. Taylor, G.P. Dalsky, R. Marcus, Teriparatide or alendronate in glucocorticoid-induced osteoporosis. N. Engl. J. Med. 357, 2028-2039 (2007)

71. B.L. Langdahl, F. Marin, E. Shane, H. Dobnig, J.R. Zanchetta, M. Maricic, K. Krohn, K. See, M.R. Warner, Teriparatide versus alendronate for treating glucocorticoid-induced osteoporosis: an analysis by gender and menopausal status. Osteoporos. Int. 20 (12), 2095-2104 (2009)

72. R.M. Neer, C.D. Arnaud, J.R. Zanchetta, R. Prince, G.A. Gaich, J. Y. Reginster, A.B. Hodsman, E.F. Eriksen, S. Ish-Shalom, H.K. Genant, O. Wang, B.H. Mitlak, Effect of parathyroid hormone (134) on fractures and bone mineral density in postmenopausal women with osteoporosis. N. Engl. J. Med. 344, 1434-1441 (2001)

73. H. Oxlund, G. Ortoft, J.S. Thomsen, C.C. Danielsen, C. Ejersted, T.T. Andreassen, The anabolic effect of PTH on bone is attenuated by simultaneous glucocorticoid treatment. Bone 39, 244-252 (2006)

74. S. Nishida, A. Yamaguchi, T. Tanizawa, N. Endo, T. Mashiba, Y. Uchiyama, T. Suda, S. Yoshiki, H.E. Takahashi, Increased bone formation by intermittent parathyroid hormone administration is due to the stimulation of proliferation and differentiation of osteoprogenitor cells in bone marrow. Bone 15, 717-723 (1994)

75. R.L. Jilka, R.S. Weinstein, T. Bellido, P. Roberson, A.M. Parfitt, S.C. Manolagas, Increased bone formation by prevention of osteoblast apoptosis by parathyroid hormone. J. Clin. Invest. 104, 439-446 (1999)

76. K.G. Saag, J.R. Zanchetta, J.P. Devogelaer, R.A. Adler, R. Eastell, K. See, J.H. Krege, K. Krohn, M.R. Warner, Effects of teriparatide versus alendronate for treating glucocorticoid-induced osteoporosis: thirty-six-month results of a randomized, doubleblind, controlled trial. Arthritis Rheum. 60, 3346-3355 (2009)

77. K.G. Saag, D. Agnusdei, D. Hans, L.A. Kohlmeier, K.D. Krohn, E.S. Leib, E.J. MacLaughlin, J. Alam, C. Simonelli, K.A. Taylor, 
R. Marcus, Trabecular bone score in patients with chronic glucocorticoid therapy-induced osteoporosis treated with alendronate or teriparatide. Arthritis Rheumatol. 68(9), 2122-2128 (2016)

78. C.C. Glüer, F. Marin, J.D. Ringe, F. Hawkins, R. Möricke, N. Papaioannu, P. Farahmand, S. Minisola, G. Martínez, J.M. Nolla, C. Niedhart, N. Guañabens, R. Nuti, E. Martín-Mola, F. Thomasius, G. Kapetanos, J. Peña, C. Graeff, H. Petto, B. Sanz, A. Reisinger, P.K. Zysset, Comparative effects of teriparatide and risedronate in glucocorticoid-induced osteoporosis in men: 18month results of the EuroGIOPs trial. J. Bone Miner. Res. 28(6), 1355-68 (2013)
79. K. Saag, N. Pannacciulli, P. Geusens, J. Adachi, E. Lespessailles, J. Malouf-Serra, O. Messina, A. Wang, R.B. Wagman, W.F. Lems, Effect of denosumab compared with risedronate on percentage change in lumbar spine BMD at 12 months in subgroups of glucocorticoid-treated individuals. American Society of Bone and Mineral Research Annual Meeting Abstracts FR0301 S109 (2017).

80. M. Maricic, C. Deal, R. Dore, A. Laster, Comment on 2017 American college of rheumatology guideline for the prevention and treatment of glucocorticoid-induced osteoporosis. Arthritis Care Res. (2017) https://doi.org/10.1002/acr.23424. 